\title{
Isolation and Characterization of Biosurfactant-Producing Bacteria from Amapaense Amazon Soils
}

\author{
Elisa Maria de Oliveira $\left(\mathbb{D},{ }^{1}\right.$ Victor Hugo Gomes Sales $(\mathbb{D})^{2}$ Marcelo Silva Andrade $(\mathbb{D})^{1}$ \\ Jerri Édson Zilli $\mathbb{D}^{3},{ }^{3}$ Wardsson Lustrino Borges $\mathbb{D}^{\mathbb{D}},{ }^{4,5}$ and Tiago Marcolino de Souza $\mathbb{D}^{1}$ \\ ${ }^{1}$ State University of Amapá, Av. Presidente Vargas, 650 Bairro Central, 68900-070 Macapá-AP, Brazil \\ ${ }^{2}$ Federal Institute of Amapá, Campus Macapá, BR 220 km 03 Bairro Brasil Novo, 68909-398 Macapá-AP, Brazil \\ ${ }^{3}$ National Center for Agrobiology Research (Embrapa Agrobiologia), Rodovia BR-465 km 7, 23897-970 Seropédica-RJ, Brazil \\ ${ }^{4}$ Embrapa Amapá, Rodovia Juscelino Kubitschek, 68903-419 Macapá-AP, Brazil \\ ${ }^{5}$ Embrapa Tropical Agroindustry, Rua Dra. Sara Mesquita 2270, 60511-110 Fortaleza-CE, Brazil
}

Correspondence should be addressed to Tiago Marcolino de Souza; uaitiago@gmail.com

Received 30 March 2021; Revised 18 July 2021; Accepted 5 August 2021; Published 17 August 2021

Academic Editor: Zhun Li

Copyright (c) 2021 Elisa Maria de Oliveira et al. This is an open access article distributed under the Creative Commons Attribution License, which permits unrestricted use, distribution, and reproduction in any medium, provided the original work is properly cited.

\begin{abstract}
The objective of this research was to perform screening of biosurfactant-producing bacteria from Amapaense Amazon soils. Floodplain- and upland-forest soils of three municipalities of the Amapá state were isolated and identified. The isolates were cultured in nutrient broth with olive oil, and their extracts were evaluated according to drop collapse, oil dispersion, emulsification, and surface tension tests. From three hundred and eighteen isolates, the 43 bacteria were selected and identified by $16 \mathrm{~S}$ rDNA gene sequencing, indicating the presence of three different genera, Serratia, Paenibacillus, and Citrobacter. The extracellular biosurfactant production pointed out the 15 most efficient bacteria that presented high emulsification capacity $\left(E_{24}>48 \%\right)$ and stability (less than $10 \%$ of drop after $72 \mathrm{~h}$ ) and great potential to reduce the surface tension (varying from 49.40 to $34.50 \mathrm{mN} \cdot \mathrm{m}^{-1}$ ). Cluster analysis classified genetically related isolates in different groups, which can be connected to differences in the amount or the sort of biosurfactants. Isolates from Serratia genus presented better emulsification capacity and produced a more significant surface tension drop, indicating a promising potential for biotechnological applications.
\end{abstract}

\section{Introduction}

Microbial surfactants or biosurfactants are intracellular or extracellular metabolites of fungi and bacteria [1] classified into different structural and functional groups: lipopeptides, glycolipids, polysaccharide-protein complexes, phospholipids, neutral lipids, and fatty acids [2]. These molecules can perform different natural roles in the growth and reproduction of microorganisms [3].

Matsuyama and Nakagawa [4] observed that Serratia marcescens formed a giant colony when inoculated at agar medium (at $30^{\circ} \mathrm{C}$ for one week). In contrast, a single round colony was verified for mutant bacteria defective in wetting-agent production. They evidenced that serrawettins played a critical role in $S$. marcescens colony growth on solid-air interfaces. For Bacillus subtilis, the surfactin production and flagellar biosynthesis were found to be essential in swarming motility [5]. Luo et al. [6] also reported that surfactin and bacillomycin L. played important roles in the antagonistic activity and swarming motility of $B$. subtilis 916 against $R$. solani through biofilm formation and colonization. The rhamnolipids produced by Pseudomonas aeruginosa exhibited antimicrobial activity against several bacterial and fungal species [7]. They cause necrotic death of polymorphonuclear leukocytes, enhance cell virulence, and reduce phagocytosis susceptibility [8]. For Pseudomonas aeruginosa, rhamnolipids could be considered a multifunctional component of a mechanism controlling fundamental elements of microbial life [9]. 
The Amazon region shows rich biodiversity, comprising various elements like animals, plants, and microorganism species. Despite the intensive efforts to study this biome and the greater knowledge about its characteristics, microbial diversity remains unexplored in the Amapaense Amazon. Microorganisms play unique and vital functions in ecosystems and biosphere maintenance; therefore, Amapaense Amazon could provide microorganisms required for developing substances of biotechnological interest [10, 11]. Thus, the aim of the present research was the isolation and screening of biosurfactant-producing bacteria from the Amapaense Amazon, Brazil. In order to achieve this aim, the objectives include (1) selection of upland- and floodplainforest soils of three municipalities using some qualitative and quantitative methods; (2) chemical and physical characterization of isolated soil samples; (3) isolation of biosurfactant-producing bacterial strains; (4) screening for biosurfactant production; and, finally, (5) identification of screened biosurfactant-producing strains by $16 \mathrm{~S}$ rDNA gene sequencing.

\section{Material and Methods}

2.1. Collection Sites. Amazonian soil samples of two different ecosystems, upland-forest (U) and floodplain-forest (F), both under equatorial forest formation, were collected in three municipalities of the Amapá State, Brazil [Ferreira Gomes (FG), Porto Grande (PG), and Mazagão (MZ)] (Figure 1). The geographic coordinates of the collection sites were as follows: FGU $\left(\mathrm{N} 00^{\circ} 50^{\prime} 07,7^{\prime \prime}\right.$; W $\left.051^{\circ} 11^{\prime} 05,2^{\prime \prime}\right)$, FGF (N 00 $49^{\prime} 49,6^{\prime \prime}$; W $\left.051^{\circ} 10^{\prime} 29,6^{\prime \prime}\right)$, PGU (N 00² $42^{\prime} 16,5^{\prime \prime}$; W $\left.051^{\circ} 23^{\prime} 15,2^{\prime \prime}\right)$, PGF (N $00^{\circ} 42^{\prime} 24,1^{\prime \prime}$; W $\left.051^{\circ} 23^{\prime} 18,3^{\prime \prime}\right)$, MZU $\left(\mathrm{S} 00^{\circ} 09^{\prime} 39,0^{\prime \prime}\right.$; W $\left.051^{\circ} 21^{\prime} 14,5^{\prime \prime}\right)$, and MZF (S $00^{\circ} 11^{\prime} 57,8^{\prime \prime}$; W $\left.051^{\circ} 21^{\prime} 47,6^{\prime \prime}\right)$. For each collection site, the ground surface was cleaned to remove plants and decomposing organic material. The soil was collected in three distinct points (in a circle with a diameter of $500 \mathrm{~cm}$ and depth of $20 \mathrm{~cm}$ ), homogenized to obtain a sample of approximately $500 \mathrm{~g}$, and transported to the laboratory under aseptic and refrigerated conditions.

\subsection{Chemical and Physical Characterization of Soil Samples.} The chemical analyses of the soil samples were performed in the Laboratory of Soil and Plant Physiology at EmbrapaAmapá, Brazil, according to procedures proposed by the Brazilian Agricultural Research Corporation (Table 1) [12].

2.3. Isolation of Biosurfactant-Producing Bacteria. To promote bacterial growth, $10 \mathrm{~g}$ of each homogenized soil sample was suspended in $90 \mathrm{~mL}$ of a peptone saline solution [0.85\% $\mathrm{NaCl} ; 0.1 \%$ peptone; $\left.\left(\mathrm{w} \cdot \mathrm{v}^{-1}\right)\right]$. The suspension was incubated at $30^{\circ} \mathrm{C}$ for one hour using an orbital shaker $(150 \mathrm{rpm})$ and then allowed to stand for $30 \mathrm{~min}$ [13]. Subsequently, supernatant aliquots of $1 \mathrm{~mL}$ were added to $99 \mathrm{~mL}$ of the nutrient broth (KASVI K25-610037, Brazil) (1.0 g of meat extract, $2.0 \mathrm{~g}$ of yeast extract, $5.0 \mathrm{~g}$ of bacteriological peptone, $5.0 \mathrm{~g}$ of sodium chloride, and $4.0 \mathrm{~mL}$ of nystatin antifungal agent per liter of distilled water; $\mathrm{pH}=6.8 \pm 0.2$ ) and incubated with orbital shaking $(150 \mathrm{rpm})$ at $30^{\circ} \mathrm{C}$ for 72 hours.

The incubated suspensions were serially diluted from $10^{-1}$ up to $10^{-8}$, according to the methodology described by Ozkan and Adiguzel [14]. Then, an aliquot of $100 \mu \mathrm{L}$ of each dilution was inoculated in agar nutrient $(1.0 \mathrm{~g}$ of meat extract, $2.0 \mathrm{~g}$ of yeast extract, $5.0 \mathrm{~g}$ of bacteriological peptone, $5.0 \mathrm{~g}$ of sodium chloride, $15.0 \mathrm{~g}$ of bacterial agar, and $4.0 \mathrm{~mL}$ of nystatin antifungal agent per liter of distilled water; $\mathrm{pH}=6.8 \pm 0.2$ ) and PIA (Pseudomonas Isolation Agar ${ }^{\circledR}$ ) media (20.0 g of bacteriological peptone, $1.4 \mathrm{~g}$ of magnesium chloride, $10.0 \mathrm{~g}$ of potassium sulfate, $0.025 \mathrm{~g}$ of Irgasan (Ciba-Geigy), and $13.6 \mathrm{~g}$ of agar per liter of distilled water; $\mathrm{pH} 7,0 \pm 0,20$ ), aiming to evaluate the occurrence of Pseudomonas genus [15]. The plates were incubated in a BOD (QUIMIS Q 316M4, Brazil) chamber for 48 hours at $30^{\circ} \mathrm{C}$. Bacterial colonies were counted in triplicate for the $10^{-6}$, $10^{-7}$, and $10^{-8}$ dilutions, and the results were expressed in terms of colony-forming units $\left(\mathrm{CFU} \mathrm{mL}^{-1}\right)$.

Bacterial phenotypic traits (colony morphological characteristics) like size, color, shape, border type, and colony relief were considered during the isolation process. Isolates were preserved under freezing $\left(-12^{\circ} \mathrm{C}\right)$ in a solution $\left(\mathrm{v} \cdot \mathrm{v}^{-1}\right)$ of $50 \%$ of nutrient broth and $50 \%$ sterilized glycerol at $20 \%$.

2.4. Biosurfactant Production. Isolates were cultured in nutrient broth with $1 \%\left(\mathrm{v} \cdot \mathrm{v}^{-1}\right)$ olive oil for 72 hours at $30^{\circ} \mathrm{C}$. After incubation, the extracts were evaluated by drop collapse, oil dispersion, and emulsification tests to identify biosurfactant-producing isolates. Isolates were registered under the code A49223C on the National Genetic Heritage Management System (SISGEN), as recommended by the Brazilian Biodiversity Law ( $\left.n^{\circ} 13.123 / 2015\right)$, and deposited at the Johanna Döbereiner Biological Resource Center (Embrapa Agrobiologia).

2.5. Screening of Biosurfactant-Producing Bacteria. The following selection criteria were adopted for screening of biosurfactant-producing bacteria: (i) at least two isolates from each collection site and (ii) all isolates with $E_{24} \geq 50 \%$. These criteria were chosen to investigate microorganisms from all studied ecosystems.

The drop collapse and oil dispersion tests were performed using the cell culture of isolates. For drop collapse, $10 \mu \mathrm{L}$ of a burned lubricating oil was added to each well of a 96-well plate and allowed to stand for 24 hours at room temperature. Then, $10 \mu \mathrm{L}$ of the culture was added to the oil's surface, and the drop shape was observed after one minute of incubation. For the oil dispersion test, the Petri dishes were filled with distilled water $(35 \mathrm{~mL})$, and the burned lubricating oil $(100 \mu \mathrm{L})$ was added to the water surface. Subsequently, $10 \mu \mathrm{L}$ of the cell culture was added to the center of the oils' surface $[16,17]$. In both cases, the positive control and negative control were realized with a $1 \%$ sodium dodecyl sulfate (SDS) solution and distilled water, respectively. The result was considered positive when the drop was totally or partially scattered and negative when it remained unchanged 


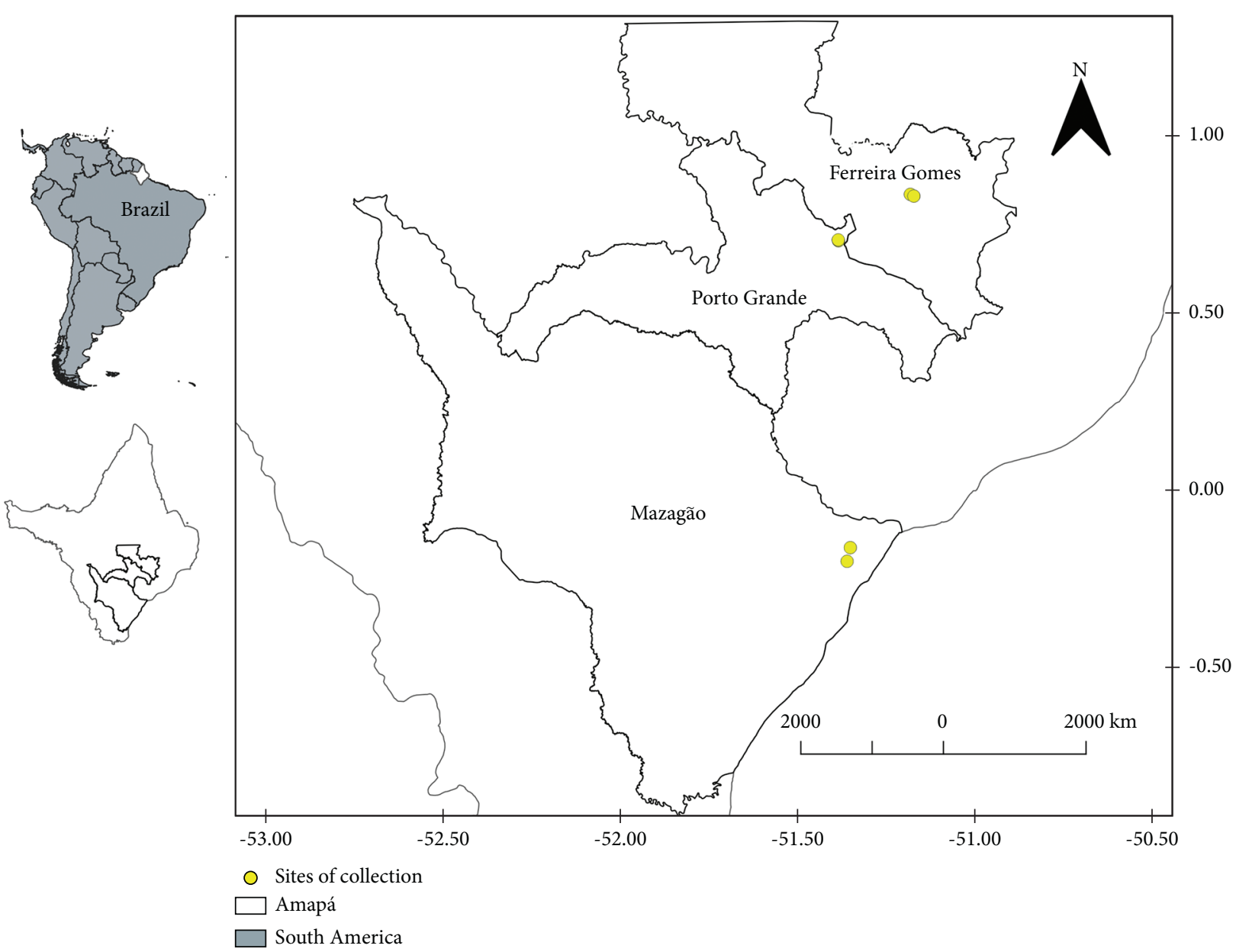

FIGURE 1: Sites of soil collection in the upland- (U-) and floodplain-forest (F) ecosystems at three municipalities: (i) Ferreira Gomes (FGU and FGF), (ii) Porto Grande (PGU and PGF), and (iii) Mazagão (MZU and MZF). Black-colored circles indicate collecting sites.

TABLe 1: Chemical and physical characteristics of soil samples from the different studied ecosystems.

\begin{tabular}{|c|c|c|c|c|c|c|}
\hline \multirow{2}{*}{ Characteristics of the soil samples } & \multicolumn{6}{|c|}{ Ecosystem codes } \\
\hline & FGU & FGF & PGU & PGF & $\mathrm{MZU}$ & $\mathrm{MZF}$ \\
\hline $\mathrm{pH}$ & 4.6 & 5.5 & 4.9 & 5.1 & 4.3 & 4.2 \\
\hline Organic matter $\left(\mathrm{mg} \cdot \mathrm{kg}^{-1}\right)$ & $3.55 \times 10^{3}$ & $1.05 \times 10^{5}$ & $2.50 \times 10^{4}$ & $4.55 \times 10^{4}$ & $6.45 \times 10^{4}$ & $4.62 \times 10^{4}$ \\
\hline Phosphorus $\left(\mathrm{mg} \cdot \mathrm{m}^{-3}\right)$ & $3.00 \times 10^{3}$ & $4.00 \times 10^{3}$ & $5.00 \times 10^{3}$ & $6.00 \times 10^{3}$ & $2.00 \times 10^{3}$ & $2.00 \times 10^{3}$ \\
\hline $\mathrm{K}^{+}\left(\mathrm{mg} \cdot \mathrm{m}^{-3}\right)$ & $1.96 \times 10^{4}$ & $1.96 \times 10^{4}$ & $2.35 \times 10^{4}$ & $2.74 \times 10^{4}$ & $2.35 \times 10^{4}$ & $2.35 \times 10^{4}$ \\
\hline $\mathrm{Ca}^{2+}+\mathrm{Mg}^{2+}\left(\mathrm{mg} \cdot \mathrm{m}^{-3}\right)$ & $9.73 \times 10^{4}$ & $9.73 \times 10^{4}$ & $8.51 \times 10^{4}$ & $1.09 \times 10^{5}$ & $6.08 \times 10^{4}$ & $4.86 \times 10^{4}$ \\
\hline $\mathrm{Ca}^{2+}\left(\mathrm{mg} \cdot \mathrm{m}^{-3}\right)$ & - & $1.20 \times 10^{5}$ & - & - & - & - \\
\hline $\mathrm{Al}\left(\mathrm{mg} \cdot \mathrm{m}^{-3}\right)$ & $1.44 \times 10^{5}$ & $6.30 \times 10^{4}$ & $9.89 \times 10^{4}$ & $1.35 \times 10^{5}$ & $1.98 \times 10^{5}$ & $3.24 \times 10^{5}$ \\
\hline $\mathrm{H}^{+}+\mathrm{Al}^{3+}\left(\mathrm{mg} \cdot \mathrm{m}^{-3}\right)$ & $2.14 \times 10^{5}$ & $1.80 \times 10^{5}$ & $1.48 \times 10^{5}$ & $2.24 \times 10^{5}$ & $2.96 \times 10^{5}$ & $4.18 \times 10^{5}$ \\
\hline $\mathrm{SB}^{*}\left(\mathrm{mg} \cdot \mathrm{m}^{-3}\right)$ & $1.17 \times 10^{5}$ & $1.17 \times 10^{5}$ & $1.09 \times 10^{5}$ & $1.37 \times 10^{5}$ & $8.42 \times 10^{4}$ & $7.21 \times 10^{4}$ \\
\hline $\mathrm{CEC}^{\bullet}\left(\mathrm{mg} \cdot \mathrm{m}^{-3}\right)$ & $3.31 \times 10^{5}$ & $2.97 \times 10^{5}$ & $2.57 \times 10^{5}$ & $3.60 \times 10^{5}$ & $3.80 \times 10^{5}$ & $4.90 \times 10^{5}$ \\
\hline Base saturation (\%) & 9 & 10 & 12 & 9 & 5 & 4 \\
\hline $\mathrm{Al}^{3+}$ saturation (\%) & 64 & 33 & 58 & 60 & 79 & 88 \\
\hline Clay (\%) & 10.1 & 34.9 & 19.8 & 17.4 & 35.9 & 25.3 \\
\hline Coarse sand (\%) & 62.5 & 0 & 48.0 & 37.5 & 10.5 & 24.5 \\
\hline Fine sand $(\%)$ & 16.5 & 0 & 24.0 & 17.0 & 9.5 & 14.0 \\
\hline Silt (\%) & 10.9 & 65.1 & 8.2 & 28.1 & 44.1 & 36.2 \\
\hline $\mathrm{BSSC}^{\star}$ & Sandy loam & Silty clay loam & Sandy loam & Sandy loam & Clay loam & Sandy \\
\hline
\end{tabular}

- Brazilian System of Soil Classification; ${ }^{*} \mathrm{SB}=\mathrm{Ca}^{2+}+\mathrm{Mg}^{2+}+\mathrm{K}^{+} ;{ }^{\bullet} \mathrm{CEC}=\mathrm{SB}+\mathrm{H}^{+}+\mathrm{Al}^{3+}$. 
[16-18]. The activity of the produced biosurfactant was classified as weak $(+)$, moderate $(++)$, and strong $(+++)$, as indicated in Figure 2.

Emulsification capacity was evaluated by adding $2.0 \mathrm{~mL}$ of commercial kerosene in a screw cap test tube containing $2.0 \mathrm{~mL}$ of cell culture, followed by vigorously mixing in a vortex (Multimixer Kasvi K40, Brazil) $3000 \mathrm{rpm}$ for $2 \mathrm{~min}$ [19]. Measurements were performed after 24, 48, and 72 hours at room temperature. The emulsification index $E_{24 \mathrm{~h}}$ was calculated by the ratio between emulsion column height after 24 hours and total column height. The stability was determined considering the column emulsion height after 48 and 72 hours $\left(E_{48 \mathrm{~h}}\right.$ and $\left.E_{72 \mathrm{~h}}\right)$, respectively.

2.6. Second Screening of Biosurfactant-Producing Bacteria. This screening evaluated the extracellular biosurfactant production by the selected microorganisms. Cell culture was carried out as previously described, and extracts were centrifuged at $6000 \mathrm{rpm}$ for $10 \mathrm{~min}$ at $4^{\circ} \mathrm{C}$ to obtain the cellfree supernatant [20]. The supernatant emulsification was measured after 24, 48, and 72 hours, as described before.

The following selection criteria were adopted in this screening: (i) at least one isolate from each of the selected ecosystems and (ii) all isolates that show emulsification index $E_{24} \geq 48 \%$ and emulsification stability (did not show more than $10 \%$ of drop after 48 and 72 hours). These criteria were established to select microorganisms with potential for biotechnological processes.

Considering the extracellular selection and aiming to confirm the isolates' potential to produce biosurfactants, they were cultured again. The cell-free supernatant was used to determine $E_{24}$ and surface tension. Surface tension was measured using a (KRUSS EASYDYN, Germany) tensiometer, according to the methodology described by Kuyukina et al. [15]. Before each test, the DU NUOY ring was sterilized using a Bunsen burner and calibrated with distilled water $\left(\sim 70.4 \pm 0.1 \mathrm{mN} \cdot \mathrm{m}^{-1}\right)$, as proposed by $\mathrm{Du}$ Noüy [21].

Obtained data were analyzed using a one-way analysis of variance (ANOVA) and means compared by the Tukey test at 5\% significance. Principal component analysis (PCA) and hierarchical cluster analysis (HCA) based on the Euclidean distance and complete linkage method were performed using the Minitab 19 software and the methodology described by Ferreira et al. [22]. Principal component analysis (PCA) based on Euclidean distance and complete linkage method was applied to evaluate similarity among analyzed strains using surface tension $(\sigma)$ and emulsification indexes $\left(E_{24}, E_{48}\right.$, and $E_{72}$ with and without cells) as descriptors. After the first PCA run, essential descriptors to describe the variance were maintained, whereas correlated ones were excluded. Surface tension $(\sigma)$ and emulsification indexes ( $E_{24}$ with and without cells) were the selected descriptors. Hierarchical cluster analysis (HCA) based on the Euclidean distance and the complete linkage method was also applied to group microorganisms based on the surface tension and emulsification indexes ( $E_{24}$ with and without cells).
The genomic DNA extraction was carried out using the Wizard ${ }^{\circledR}$ Genomic DNA kit (Promega, Madison, WI, USA), following the manufacturer's recommendations. DNA concentration was measured by spectrophotometry at $260 \mathrm{~nm}$ (NanoDrop, Thermo Fisher Scientific, Waltham, MA, USA), and their integrity was verified on agarose gel at $1 \%\left(\mathrm{w} \cdot \mathrm{v}^{-1} ; 60 \mathrm{~V} ; 1 \mathrm{~h}\right)$. The $16 \mathrm{~S}$ rDNA gene was amplified with the primers 27F $5^{\prime}$-AGA GTT TGA TCC TGG CTC AG- $3^{\prime}$ and 1492R $5^{\prime}$-GGT TAC CTT GTT ACG ACT T-3'. The PCR was realized on a thermal cycler (Applied Biosystems ${ }^{\mathrm{TM}}$ SimpliAmp) under the following conditions: $1.5 \mathrm{U}$ Taq DNA polymerase, $1 \mathrm{x}$ PCR buffer $(10 \mathrm{mM}$ of Tris- $\mathrm{HCl} \mathrm{pH} 8$ and $50 \mathrm{mM}$ of $\mathrm{KCl}$ ), $1.75 \mathrm{mM}$ of $\mathrm{MgCl}_{2}, 0.25 \mathrm{mM}$ of each dNTP, $0.2 \mu \mathrm{M}$ of each primer, and $1 \mu \mathrm{L}$ of the DNA template, with a total volume of $50 \mu \mathrm{L}$. Amplification was performed using initial denaturation at $94^{\circ} \mathrm{C}$ for $3 \mathrm{~min}$, followed by 29 cycles of denaturation at $94^{\circ} \mathrm{C}$ for $1 \mathrm{~min}$, annealing at $58^{\circ} \mathrm{C}$ for $1 \mathrm{~min}$, extension at $72^{\circ} \mathrm{C}$ for $2 \mathrm{~min}$ and, and a final extension at $72^{\circ} \mathrm{C}$ for $7 \mathrm{~min}$.

Sequencing reactions were carried out using a DYEnamic $^{\mathrm{TM}}$ ET Dye Terminator kit $\left(\mathrm{MegaBACE}^{\mathrm{TM}}\right)$ and an automatic MegaBACE 1000 sequencer (GE Healthcare Life Sciences). The obtained sequences were deposited at the NCBI GenBank, with accessions numbers MK156425MK156460 and MT252662-MT252668. Then the obtained sequences were compared with the National Center Biotechnology Information database (http://www.ncbi.nlm.nih. gov) using the BLAST tool [23]. Subsequently, the sequences were aligned using the Cluster $\mathrm{W}$ program, and the phylogenetic tree was built based on the method of maximum likelihood [24] with the aid of the Mega X software [25]. Finally, the isolates' phylogeny was analyzed using the maximum likelihood method and the Tamura-Nei model, including bootstrap analysis based on 1000 replications [24] to estimate the confidence level of the tree topology.

\section{Results}

Amazonian soil samples collected from two different ecosystems have shown a significant number of CFU. The number of counted microorganisms per milliliter (CFU $\left.\mathrm{mL}^{-1}\right)$ was $3.96 \times 10^{9}, 2.25 \times 10^{9}, 1.67 \times 10^{9}, 1.69 \times 10^{9}$, $2.41 \times 10^{9}$, and $4.95 \times 10^{9}$ for the FGU, FGF, PGU, PGF, MZU, and MZF ecosystems, respectively. A total of 318 bacteria were isolated (Table 2). Upland-forests (FGU, PGU, and MZU) showed greater bacterial populational density than floodplain ones (FGF, PGF, and MZF), 227 and 91 isolates, respectively. The FGU alone presented 138 isolates, which corresponds to $43,4 \%$ of the total isolated bacteria.

For the drop collapse test, 237, 73, and 8 isolates presented weak, moderate, and strong activities, respectively. For the oil dispersion tests, 204, 113, and 1 isolates demonstrated weak, moderate, and strong activities, respectively. Table 3 presents the results attained for the 43 bacterial isolates chosen in the first screening.

A total of 15 isolates were selected in the second screening (Table 2). Concerning the biosurfactants' production with and without cells, emulsification results for MZU32 and MZF02 have presented significant differences 


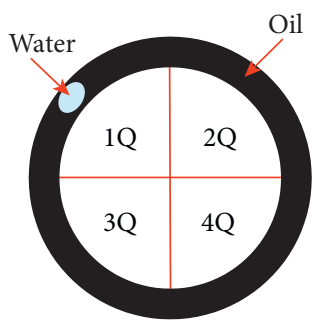

Negative Control (water)

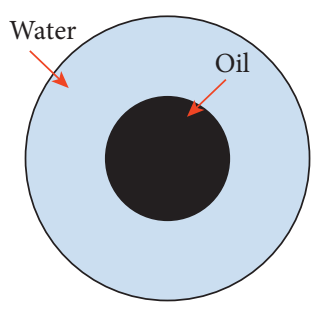

Negative Control (water)

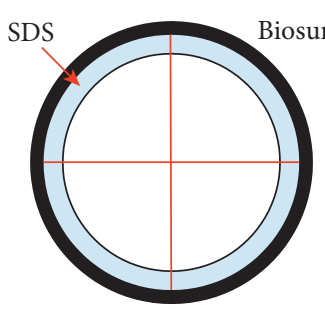

Positive Control (SDS)

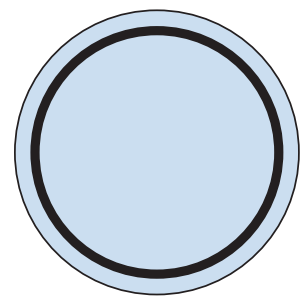

Positive Control

(SDS)

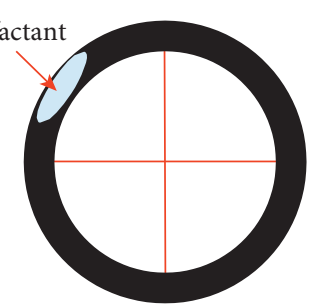

$(+)$

(a)

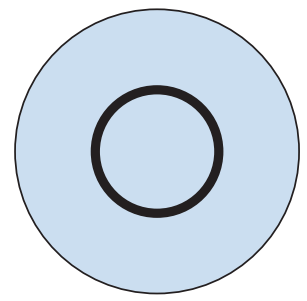

$(+)$

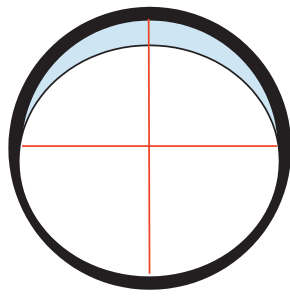

$(++)$

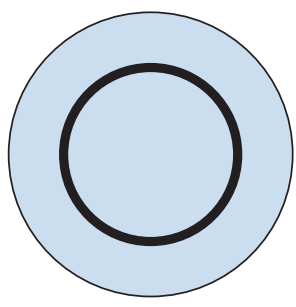

$(++)$

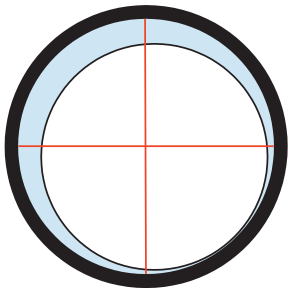

$(+++)$

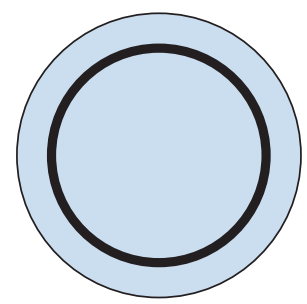

$(+++)$

(b)

FIGURE 2: Schematic representation of the qualitative tests used to evaluate the isolated bacterial strains' capacity to produce biosurfactants: (a) drop collapse test, where $1 \mathrm{Q}, 2 \mathrm{Q}, 3 \mathrm{Q}$, and $4 \mathrm{Q}$ represent the first, second, third, and fourth quadrants; (b) oil dispersion test.

TABLE 2: Total number of isolates and the number of biosurfactant-producing isolates after the first and second screening stages.

\begin{tabular}{lccccc}
\hline Items & FGU & FGF & PGU & PGF & MZU \\
\hline Total number of isolates & 138 & 30 & 47 & 59 & 42 \\
First screening & 17 & 13 & 3 & 6 & 2 \\
Second screening & 7 & 4 & 1 & 1 & 2 \\
\hline
\end{tabular}

TABLE 3: Drop collapse, oil dispersion, and emulsification (with and without cells) results for microorganisms selected in the first screening.

\begin{tabular}{|c|c|c|c|c|c|c|c|c|}
\hline \multirow[t]{2}{*}{ Codes of the isolated microorganisms } & \multirow[t]{2}{*}{ Drop collapse } & \multirow[t]{2}{*}{ Oil dispersion } & \multicolumn{3}{|c|}{$\begin{array}{c}\text { First screening } \\
\text { Emulsification index } \\
\text { (\%) (with cells) }\end{array}$} & \multicolumn{3}{|c|}{$\begin{array}{l}\text { Second screening } \\
\text { Emulsification index } \\
(\%) \text { (cell-free) }\end{array}$} \\
\hline & & & $24 \mathrm{~h}$ & $48 \mathrm{~h}$ & $72 \mathrm{~h}$ & $24 \mathrm{~h}$ & $48 \mathrm{~h}$ & $72 \mathrm{~h}$ \\
\hline FGU02 & + & + & 62.2 & 11.4 & 6.7 & 4.4 & 4.4 & 4.4 \\
\hline FGU12 & + & + & 64.4 & 53.5 & 51.2 & 15.9 & 6.8 & 6.7 \\
\hline FGU14 & +++ & ++ & 58.1 & 55.8 & 55.8 & 50.0 & 50.0 & 47.7 \\
\hline FGU82 & ++ & ++ & 63.6 & 59.1 & 56.8 & 55.6 & 53.3 & 53.3 \\
\hline FGU83 & + & + & 51.1 & 51.2 & 48.8 & 15.6 & 15.6 & 15.6 \\
\hline FGU86 & + & + & 51.2 & 45.5 & 45.5 & 47.7 & 45.5 & 45.5 \\
\hline FGU92 & + & + & 52.3 & 17.8 & 11.4 & 48.9 & 48.9 & 48.9 \\
\hline FGU94 & + & + & 50.0 & 40.9 & 38.6 & 28.9 & 26.7 & 26.7 \\
\hline FGU100 & + & + & 53.3 & 44.4 & 44.4 & 53.3 & 53.3 & 53.3 \\
\hline FGU101 & +++ & +++ & 52.3 & 45.5 & 45.5 & 60.9 & 60.9 & 60.9 \\
\hline FGU104 & + & + & 50.0 & 46.7 & 46.7 & 48.9 & 48.9 & 48.9 \\
\hline FGU107 & + & + & 65.1 & 50.0 & 51.2 & 45.7 & 32.6 & 32.6 \\
\hline FGU109 & + & + & 68.2 & 66.7 & 65.9 & 28.9 & 28.9 & 22.2 \\
\hline FGU113 & + & + & 50.0 & 37.8 & 26.7 & 35.6 & 35.6 & 22.2 \\
\hline FGU121 & + & + & 50.0 & 48.9 & 48.9 & 51.1 & 51.1 & 51.1 \\
\hline FGU125 & + & + & 52.3 & 50.0 & 50.0 & 33.3 & 33.3 & 31.1 \\
\hline FGU132 & + & + & 63.6 & 50.0 & 50.0 & 6.7 & 6.7 & 6.7 \\
\hline FGF05 & + & + & 51.1 & 46.7 & 46.7 & 44.4 & 42.2 & 42.2 \\
\hline
\end{tabular}


TABLE 3: Continued.

\begin{tabular}{|c|c|c|c|c|c|c|c|c|}
\hline \multirow{3}{*}{ Codes of the isolated microorganisms } & \multirow{3}{*}{ Drop collapse } & \multirow{3}{*}{ Oil dispersion } & \multicolumn{3}{|c|}{ First screening } & \multicolumn{3}{|c|}{ Second screening } \\
\hline & & & \multicolumn{3}{|c|}{$\begin{array}{c}\text { Emulsification index } \\
\text { (\%) (with cells) }\end{array}$} & \multicolumn{3}{|c|}{$\begin{array}{l}\text { Emulsification index } \\
(\%) \text { (cell-free) }\end{array}$} \\
\hline & & & $24 \mathrm{~h}$ & $48 \mathrm{~h}$ & $72 \mathrm{~h}$ & $24 \mathrm{~h}$ & $48 \mathrm{~h}$ & $72 \mathrm{~h}$ \\
\hline FGF07 & + & + & 52.3 & 52.3 & 50.0 & 50.0 & 2.0 & 2.0 \\
\hline FGF09 & + & ++ & 55.6 & 51.1 & 51.1 & 37.0 & 32.6 & 32.6 \\
\hline FGF12 & + & + & 53.3 & 51.1 & 51.1 & 50.0 & 4.3 & 2.2 \\
\hline FGF13 & +++ & ++ & 50.0 & 36.4 & 31.8 & 15.6 & 15.6 & 13.3 \\
\hline FGF15 & ++ & ++ & 58.7 & 56.5 & 50.0 & 60.0 & 60.0 & 60.0 \\
\hline FGF17 & + & + & 56.5 & 47.8 & 45.7 & 54.3 & 54.3 & 54.3 \\
\hline FGF19 & + & + & 60.9 & 58.7 & 58.7 & 58.7 & 56.5 & 56.5 \\
\hline FGF20 & + & + & 50.0 & 50.0 & 50.0 & 55.6 & 55.6 & 55.6 \\
\hline FGF24 & + & + & 56.8 & 56.8 & 54.5 & 46.7 & 46.7 & 44.4 \\
\hline FGF25 & + & + & 62.2 & 51.1 & 60.0 & 44.4 & 42.2 & 42.2 \\
\hline FGF26 & + & + & 56.5 & 52.2 & 50.0 & 17.8 & 6.7 & 6.7 \\
\hline FGF30 & + & + & 55.6 & 53.3 & 53.3 & 23.3 & 16.3 & 14.0 \\
\hline PGU05 & ++ & ++ & 58.7 & 52.2 & 52.2 & 28.9 & 28.9 & 22.2 \\
\hline PGU12 & ++ & ++ & 62.8 & 16.3 & 2.3 & 57.8 & 57.8 & 55.6 \\
\hline PGU25 & + & + & 56.5 & 54.3 & 54.3 & 20.0 & 13.3 & 11.1 \\
\hline PGF03 & + & ++ & 54.3 & 52.2 & 52.2 & 9.3 & 9.3 & 7.0 \\
\hline PGF04 & + & + & 60.0 & 57.8 & 55.6 & 6.7 & 6.7 & 6.7 \\
\hline PGF05 & ++ & + & 57.8 & 57.8 & 55.6 & 8.9 & 8.9 & 6.7 \\
\hline PGF34 & ++ & ++ & 51.2 & 51.2 & 46.5 & 40.9 & 40.9 & 40.9 \\
\hline PGF35 & ++ & + & 54.3 & 52.2 & 52.2 & 31.8 & 29.5 & 29.5 \\
\hline PGF46 & + & + & 52.3 & 52.3 & 52.3 & 13.3 & 13.3 & 13.3 \\
\hline MZU14 & + & + & 52.3 & 52.3 & 52.3 & 4.4 & 4.4 & 2.2 \\
\hline MZU32 & +++ & ++ & 63.0 & 63.0 & 63.0 & 40.0 & 40.0 & 37.8 \\
\hline MZF01 & + & + & 23.9 & 23.9 & 19.6 & 0 & 0 & 0 \\
\hline MZF02 & ++ & + & 21.3 & 12.8 & 12.8 & 44.4 & 44.4 & 44.4 \\
\hline
\end{tabular}

and highlighted the fundamental role of the extracellular evaluations (Table 3).

Bacteria selected in the first screening belong to three genera: 36 from Serratia, 6 from Citrobacter, and 1 from Paenibacillus (Figure 3). The group comprised of PGF03, PGF04, PGF05, PGF34, PGF35, PGF46, PGU05, FGF07, FGF09, FGF12, FGF13, FGF15, FGF24, FGF26, FGU92, MZU14, MZU32, MZF01, and MZF02 presented high similarity (>99.0\%) with the Serratia surfactantfaciens YD25 (KM093865) strain. For example, the 16S rDNA sequence identity of FGF24 (MK156451) with this strain was $99.64 \%$. The phylogenetic analysis also showed a group of isolates (FGU12, FGU14, FGU83, FGU86, FGU94, FGU100, FGU101, FGU104, FGU113, FGU121, FGU125, and FGF17) closely related to Serratia marcescens JCM1239 (AB594756) strain, all of them with identity $>99.0 \%$. Citrobacter murliniae CDC 2970-59 (NR 028688) was the closest strain to FGU 107 (MK156444), with 99.78\% similarity. The analysis placed FGU 109 (MT252663) in the vicinity of Citrobacter braakii CIP 104554 (KM515967), with 99.57\% 16S rDNA sequence identity. FGF20 (MK156435) was placed in the neighborhood of Paenibacillus favisporus GMP01 (NR029071) strain with $99.49 \%$ similarity.

The 15 bacteria selected in the second screening were cultured again, and cell-free supernatant was used to determine the emulsification index $\left(E_{24}\right)$ and surface tension $(\sigma)$. The variables showed significant differences (Table 4) and were compared using the Tukey test (Table 5). Eleven isolates presented $E_{24}>48 \%$, whereas the surface tension ranged from 34.50 to $49.4 \mathrm{mN} \cdot \mathrm{m}^{-1}$.

The score plot of the first and second components showed a separation of five distinct groups of isolates, $G 1$, G2, G3, G4, and G5 (Figure 4(a)). The clustering results as a function of isolates similarity are shown in Figure 4(b). According to the established Fenon line (dashed line), five clusters were observed, reproducing the pattern observed in PCA and highlighting more details about the similarity among the isolates in each group.

\section{Discussion}

The present study was conducted to isolate and screen biosurfactant-producing bacteria from the Amapaense Amazon, Brazil. It considered upland- and floodplain-forest soils of three municipalities. In Ferreira Gomes and Porto Grande municipalities, floodplain soils presented higher $\mathrm{pH}$ values than upland ones. A similar result was attained by Fajardo et al. [26] who analyzed floodplain and forest soils in the Amazonas state. Only the FGF and MZU samples presented high organic matter content $(>5 \%)$. The variation in soil microbial diversity and population can be affected by different factors such as $\mathrm{pH}$ (indicated as the best predictor of soil bacterial diversity and richness) [27], spatial influence [28], and soil organic matter [29]. Delgado-Baquerizo et al. [30] indicated that total carbon was positively related to soil bacterial diversity and was one of the most critical factors. 


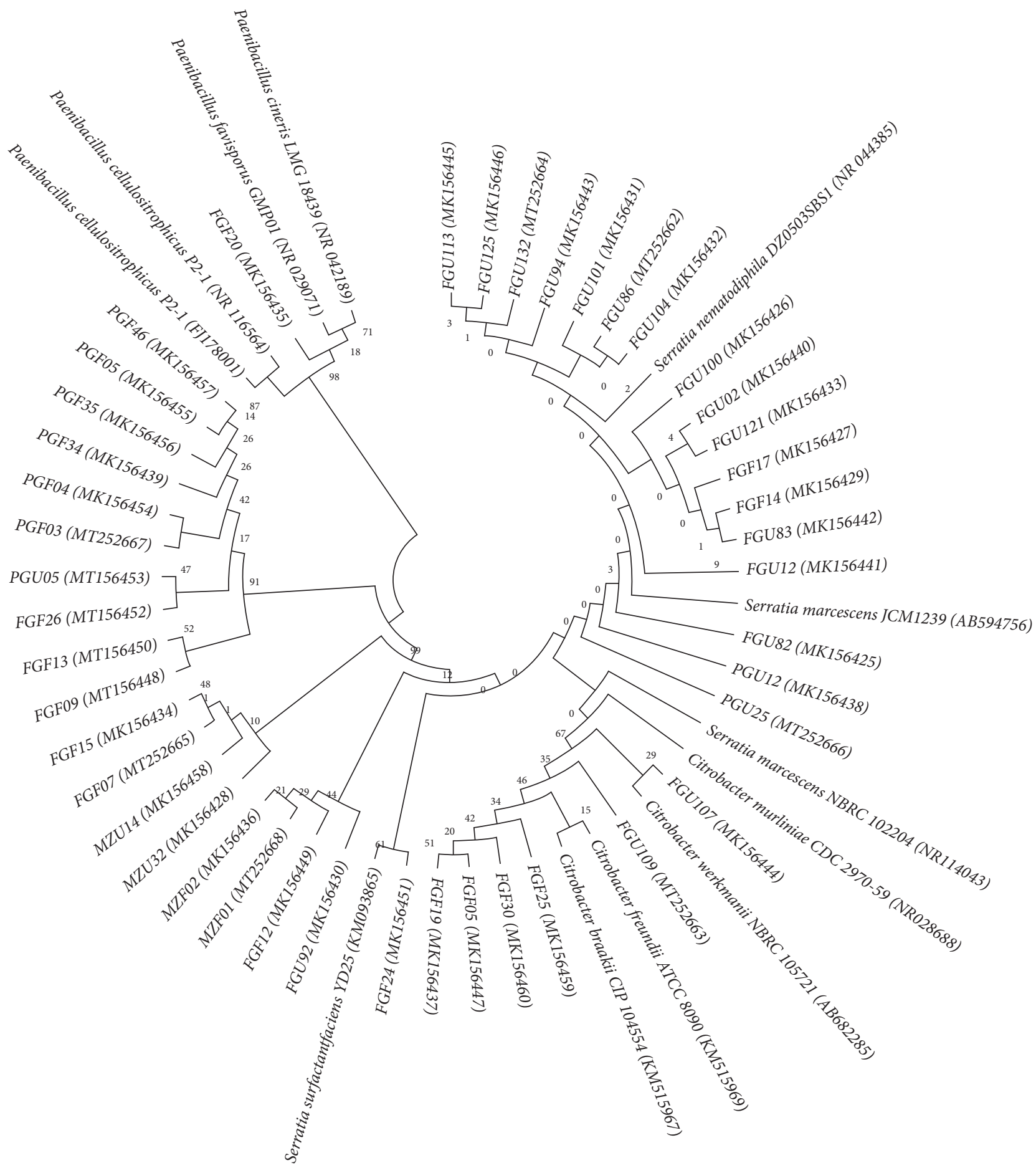

FIgUre 3: Phylogenetic analysis of the bacterial strains. The evolutionary history was inferred by using the maximum likelihood method and Tamura-Nei model [24]. The tree with the highest log likelihood (-3857.63) is shown. This analysis involved 55 nucleotide sequences. There were a total of 1439 positions in the final dataset. Evolutionary analyses were conducted in MEGA X [25].

These authors have also suggested the following: (i) bacterial diversity decreases with altitude in terrestrial ecosystems; (ii) extreme climatic conditions are the main drivers of altitude effects; and (iii) poorer bacterial diversity of southern hemisphere soils can be associated with the lower carbon content and microbial turnover rates. On the other hand, Wieder et al. [31] indicated that bacteria diversity might be limited only under very low carbon conditions. The analysis of the bacterial biodiversity is beyond the scope of this first screening of the Amapaense Amazon soil. Nonetheless, the soil samples' characterization may be helpful in future studies.

FGU101 and FGF17 isolates presented high emulsification indexes but showed strong and weak activity in 
TABLE 4: ANOVA results for surface tension and emulsification tests.

\begin{tabular}{|c|c|c|c|c|c|}
\hline Source & Degrees of freedom & Sum of squares & Mean square & $F$ & $p$ value \\
\hline & \multicolumn{5}{|c|}{ Surface tension } \\
\hline Microorganisms (between) & 14 & 938.528 & 67.0377 & 3351.89 & $\leq 0.001$ \\
\hline Error (within) & 30 & 0.600 & 0.0200 & - & - \\
\hline \multirow[t]{2}{*}{ Total } & 44 & 939.128 & - & - & - \\
\hline & \multicolumn{5}{|c|}{ Emulsification index } \\
\hline Microorganisms (between) & 14 & 1785.57 & 127.541 & 208.93 & $\leq 0.001$ \\
\hline Error (within) & 30 & 18.31 & 0.610 & - & - \\
\hline Total & 44 & 1803.88 & - & - & - \\
\hline
\end{tabular}

TABLE 5: Surface tension and emulsification index results for the bacteria in the second screening.

\begin{tabular}{|c|c|c|}
\hline \multirow[b]{2}{*}{ Codes of the isolated microorganisms } & \multicolumn{2}{|c|}{ Mean $\pm \mathrm{SD}^{*}$} \\
\hline & $\begin{array}{l}\text { Surface tension } \\
\sigma\left(m \mathrm{~N} \mathrm{~m}^{-1}\right)\end{array}$ & $\begin{array}{c}\text { Emulsification index } \\
E_{24} \mathrm{~h}(\%)\end{array}$ \\
\hline FGU14 & $34.93^{\mathrm{k}} \pm 0.06$ & $51.17^{\mathrm{f}} \pm 0.71$ \\
\hline FGU82 & $36.40^{\mathrm{hi}} \pm 0.00$ & $54.67^{\mathrm{de}} \pm 0.58$ \\
\hline FGU92 & $37.37^{\mathrm{e}} \pm 0.06$ & $48.27^{\mathrm{g}} \pm 0.47$ \\
\hline FGU100 & $37.20^{\mathrm{ef}} \pm 0.00$ & $52.60^{\mathrm{ef}} \pm 0.70$ \\
\hline FGU101 & $37.27^{\mathrm{ef}} \pm 0.06$ & $60.27^{\mathrm{a}} \pm 0.81$ \\
\hline FGU104 & $35.87^{\mathrm{j}} \pm 0.06$ & $47.80^{\mathrm{g}} \pm 0.59$ \\
\hline FGU121 & $36.73^{\mathrm{gh}} \pm 0.06$ & $51.43^{\mathrm{f}} \pm 1.37$ \\
\hline FGF15 & $36.13^{\mathrm{ij}} \pm 0.06$ & $59.73^{\mathrm{ab}} \pm 0.76$ \\
\hline FGF17 & $36.93^{\mathrm{fg}} \pm 0.06$ & $54.03^{\mathrm{de}} \pm 0.25$ \\
\hline FGF 19 & $49.40^{\mathrm{a}} \pm 0.20$ & $57.73^{b c} \pm 1.15$ \\
\hline FGF20 & $48.63^{\mathrm{b}} \pm 0.15$ & $55.60^{\mathrm{cd}} \pm 1.01$ \\
\hline PGU12 & $38.13^{\mathrm{d}} \pm 0.06$ & $57.27^{\mathrm{c}} \pm 0.73$ \\
\hline PGF34 & $44.60^{c} \pm 0.46$ & $41.03^{\mathrm{i}} \pm 0.30$ \\
\hline MZU32 & $38.50^{\mathrm{d}} \pm 0.00$ & $39.33^{\mathrm{i}} \pm 0.85$ \\
\hline MZF02 & $34.50^{1} \pm 0.00$ & $43.60^{\mathrm{h}} \pm 0.15$ \\
\hline Mean & 38.84 & 51.64 \\
\hline Coefficient of variation & 0.22 & 1.37 \\
\hline
\end{tabular}

*SD: standard deviation; means followed by the same case letters in the same column do not differ from each other by the Tukey test at $5 \%$ significance.

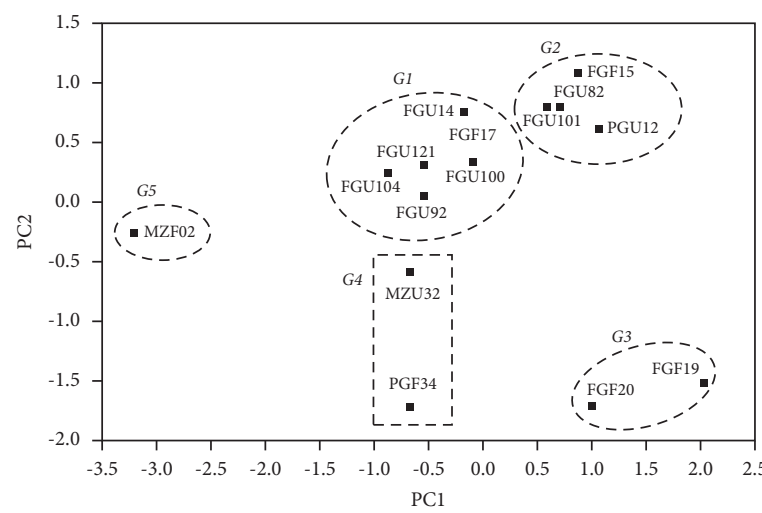

(a)

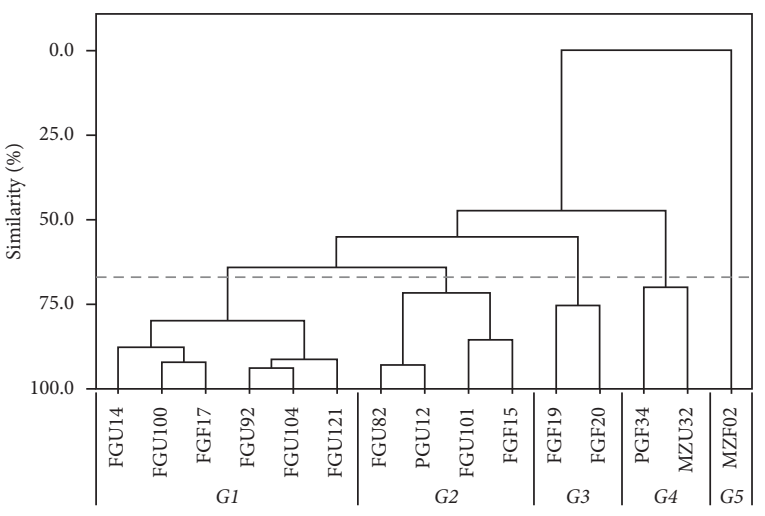

(b)

FIGURE 4: Plots of PC1-PC2 scores (a) and HCA dendrogram (b) for the biosurfactant-producing isolates based on the surface tension $(\sigma)$ and emulsification indexes ( $E_{24}$ with and without cells) results. $G 1, G 2, G 3, G 4$, and $G 5$ indicate formed groups. Fenon line is indicated by the dashed line perpendicular to the HCA similarity axis.

qualitative tests, respectively (Table 3 ). This comparison illustrates that drop collapse and oil dispersion tests, as used in this work, favored the identification of biosurfactantproducing isolates but did not allow a consistent rating of the isolates' potential. On the other hand, the emulsification index (quantitative) permitted the detection of biosurfactant-producing bacteria and provided a more consistent rating of the isolated microorganisms (Table 3).

Some studies have reported the importance of applying different screening methods to prospect biosurfactant- 
producing microorganisms $[16,32]$. In the present work, two qualitative methods (drop collapse and oil dispersion) and a quantitative one (emulsification) were applied. Further, Jain et al. [17] affirmed that the qualitative drop collapse test has a high correlation with surface tension due to the biosurfactant's ability to destabilize the liquid droplets on the oily surface. Meanwhile, Ariech and Guechi [16] also reported several isolated microorganisms that presented high, moderate, and weak capacity to collapse the oily surface. Regarding the qualitative oil dispersion test, the diameter of the central clear zone generated by the oil displacement indicates biosurfactant effectiveness. Furthermore, it has a linear relationship with the amount of biosurfactant produced [19, 32]. Various researchers have suggested that qualitative methods are more reliable for prospecting biosurfactant-producing microorganisms $[16,18]$.

Emulsification test is a straightforward quantitative method to prospect biosurfactant-producing microorganisms [16]. An emulsification index $\left(E_{24}\right)$ higher than $50 \%$ has already been used as a criterion to select biosurfactantproducing isolates. Concerning the hydrophobic compounds in various screening processes, kerosene is the most widely used one [20,33].

Emulsification capacity is strongly affected by the produced metabolite, which also depends on the bacteria genus and producer strain [34]. Bacteria selected in this work belong to Serratia, Citrobacter, and Paenibacillus genera, which can produce distinct metabolites. Serratia is a facultative anaerobic Gram-negative bacterium that belongs to the Enterobacteriaceae family and Gammaproteobacteria class [35]. Isolates belonging to this genus were able to produce lipase (Serratia sp. W3), prodigiosin (Serratia marcescens FZSF02) [36, 37], and biosurfactant [38]. Furthermore, they can promote plant growth by solubilizing phosphates [39]. Citrobacter genus also belongs to Enterobacteriaceae family and Gammaproteobacteria class and can be classified as a facultative anaerobic non-lactose-fermenting Gram-negative bacteria [40]. Paenibacillus genus belongs to Paenibacillaceae family and Bacilli class. Their colonies are smooth and translucent, with colors ranging from light brown to white, facultative anaerobic Grampositive, or strict aerobic [41]. Some studies also report biosurfactant production by Paenibacillus alvei [42], Paenibacillus sp. [43], Citrobacter murliniae [44], and Citrobacter freundii [45].

Determination of the surface tension reduction by bacterial cultivation medium has been recommended to confirm the ability of isolates to produce biosurfactants $[46,47]$. Microorganisms able to reduce the surface tension by $20 \mathrm{mN} \cdot \mathrm{m}^{-1}$, when compared with distilled water, were classified by Willumsen and Karlson [48] as promising biosurfactant producers. All the 15 selected strains decreased the broth surface tension by a value superior to the minimum established. The higher and lower surface tension reduction corresponded to $35.9 \mathrm{mN} \cdot \mathrm{m}^{-1}$ (for MZF02) and $21.0 \mathrm{mN} \cdot \mathrm{m}^{-1}$ (for FGF19), respectively (Table 5).

The first two principal components (PC1 and PC2) explained $78.9 \%$ of the total variance among analyzed strains. In the PC1 axis, emulsification indexes ( $E_{24}$ with and without cells) showed load coefficients slightly higher than surface tension one, but the three selected descriptors contributed positively to the separation of groups. Concerning PC2, $\sigma$ presented a negative and comparatively higher load and was the most crucial variable to separate the isolates in the graph vertically. PCA analysis did not show outliers, proving that data are within the acceptable region. $G 1$ represents isolates that produce biosurfactants with high emulsification capacity, which can significantly reduce the cultivation medium's surface tension. Bacteria from G2 are very similar to those from $G 1$ but with slightly lower emulsification capacity. G3 group represents microorganisms that promoted the lowest surface tension reduction and do not belong to the Serratia genus. Finally, isolates generated from $G 4$ and $G 5$ groups presented low emulsification capacity and produced medium and high surface tension drop, respectively. The descriptor variation in each dendrogram cluster did not show a defined pattern, possibly due to differences among isolates. A branch on the dendrogram bottom represents a single sample, whereas the branch length linking two clusters is related to their similarity [22]. The shorter the branch is, the higher the similarity is. The groups on the left side of the dendrogram (G1 and G2) are composed of bacteria that produce metabolites with high emulsification capacity significantly reducing the medium surface tension (Figure 4(b)). The MZF02 branch length indicates low similarity in the isolate's potential to produce biosurfactants compared to the others. PCA and HCA results suggested differences in the amount of biosurfactant or the surface-active compounds by each group of bacteria, indicating that further characterizations may be useful to understand the observed pattern.

\section{Conclusions}

Biosurfactants usage has been increasing in various industrial sectors due to the growing demand for eco-friendly materials. In this work, we have isolated and characterized biosurfactant-producing bacteria from floodplain and upland Amapaense Amazon soils, Brazil. The isolates' extracts were evaluated using drop collapse, oil dispersion, emulsification, and surface tension tests, and the selected microorganisms were identified by $16 \mathrm{~S}$ rDNA gene sequencing. 43 biosurfactant-producing bacteria belonging to Serratia, Paenibacillus, and Citrobacter genera were identified. Among these isolates, 15 were selected due to the higher emulsification capacity and potential to reduce surface tension. Ferreira Gomes municipality concentrated most of the isolates, and Serratia strains attained significantly higher emulsification indexes and surface tension reductions for the tested conditions. Further studies are required for the identification of metabolites produced by these isolates and for the optimization of biosurfactant production.

\section{Data Availability}

The experimental data used to support the findings of this study are included within the article. 


\section{Conflicts of Interest}

The authors declare that they have no known conflicts of interest or personal relationships that could have appeared to influence the work reported in this paper.

\section{Acknowledgments}

The authors are grateful to the postgraduate program in Biodiversity and Biotechnology (Rede Bionorte), the State University of Amapá (UEAP), and the Brazilian Agricultural Research Corporation (Embrapa Amapá and Embrapa Agrobiologia) for the analysis and facilities.

\section{References}

[1] R. Thavasi, S. Jayalakshmi, and I. M. Banat, "Application of biosurfactant produced from peanut oil cake by lactobacillus delbrueckii in biodegradation of crude oil," Bioresource Technology, vol. 102, no. 3, pp. 3366-3372, 2011.

[2] S. Cappello, M. Genovese, C. Della Torre et al., "Effect of bioemulsificant exopolysaccharide (EPS2003) on microbial community dynamics during assays of oil spill bioremediation: a microcosm study," Marine Pollution Bulletin, vol. 64, no. 12, pp. 2820-2828, 2012.

[3] E. Z. Ron and E. Rosenberg, "Natural roles of biosurfactants. Minireview," Environmental Microbiology, vol. 3, no. 4, pp. 229-236, 2001.

[4] T. Matsuyama and Y. Nakagawa, "Bacterial wetting agents working in colonization of bacteria on surface environments," Colloids and Surfaces B: Biointerfaces, vol. 7, no. 5-6, pp. 207-214, 1996.

[5] D. B. Kearns and R. Losick, "Swarming motility in undomesticated Bacillus subtilis," Molecular Microbiology, vol. 49, no. 3, pp. 581-590, 2003.

[6] C. Luo, H. Zhou, J. Zou et al., "Bacillomycin L and surfactin contribute synergistically to the phenotypic features of $B a$ cillus subtilis 916 and the biocontrol of rice sheath blight induced by Rhizoctonia solani," Applied Microbiology and Biotechnology, vol. 99, no. 4, pp. 1897-1910, 2015.

[7] E. Haba, A. Pinazo, O. Jauregui, M. J. Espuny, M. R. Infante, and A. Manresa, "Physicochemical characterization and antimicrobial properties of rhamnolipids produced by Pseudomonas aeruginosa 47T2 NCBIM 40044," Biotechnology and Bioengineering, vol. 81, no. 3, pp. 316-322, 2003.

[8] M. Van Gennip, L. D. Christensen, M. Alhede et al., "Inactivation of the RhlA gene in Pseudomonas aeruginosa prevents rhamnolipid production, disabling the protection against polymorphonuclear leukocytes," Apmis, vol. 117, no. 7, pp. 537-546, 2009.

[9] Ł. Chrzanowski, Ł. Ławniczak, and K. Czaczyk, "Why do microorganisms produce rhamnolipids?" World Journal of Microbiology and Biotechnology, vol. 28, no. 2, pp. 401-419, 2012.

[10] M. M. Ramos, E. d. S. Morais, I. d. S. Sena et al., "Silver nanoparticle from whole cells of the fungi trichoderma spp. isolated from Brazilian Amazon," Biotechnology Letters, vol. 42, no. 5, pp. 833-843, 2020.

[11] F. H. e. Holanda, W. G. Birolli, E. d. S. Morais et al., "Study of biodegradation of chloramphenicol by endophytic fungi isolated from bertholletia excelsa (Brazil nuts)," Biocatalysis and Agricultural Biotechnology, vol. 20, Article ID 101200, 2019.
[12] H. G. dos Santos, P. K. T. Jacomine, L. H. C. dos Anjos et al., Sistema brasileiro de classificação de solos, Embrapa Solos, Rio de Janeiro, Brazil, 5th edition, 2018.

[13] R. D. Rufino, J. M. Luna, L. A. Sarubbo, L. R. M. Rodrigues, J. A. C. Teixeira, and G. M. Campos-Takaki, "Antimicrobial and anti-adhesive potential of a biosurfactant rufisan produced by Candida lipolytica UCP 0988," Colloids and Surfaces B: Biointerfaces, vol. 84, no. 1, pp. 1-5, 2011.

[14] B. M. Ozkan and A. Adiguzel, "Isolation, identification and molecular characterization of cellulolytic bacteria from rumen samples collected from erzurum slaughter house, Turkey," Research Journal of Biotechnology, vol. 11, no. 2, pp. 32-38, 2016.

[15] M. S. Kuyukina, I. B. Ivshina, J. C. Philp, N. Christofi, S. A. Dunbar, and M. I. Ritchkova, "Recovery of rhodococcus biosurfactants using methyl tertiary-butyl ether extraction," Journal of Microbiological Methods, vol. 46, no. 2, pp. 149-156, 2001.

[16] M. Ariech and A. Guechi, "Assessment of four different methods for selecting biosurfactant producing extremely halophilic bacteria," African Journal of Biotechnology, vol. 14, no. 21, pp. 1764-1772, 2015.

[17] D. K. Jain, D. L. Collins-Thompson, H. Lee, and J. T. Trevors, "A drop-collapsing test for screening surfactant-producing microorganisms," Journal of Microbiological Methods, vol. 13, no. 4, pp. 271-279, 1991.

[18] N. H. Youssef, K. E. Duncan, D. P. Nagle, K. N. Savage, R. M. Knapp, and M. J. McInerney, "Comparison of methods to detect biosurfactant production by diverse microorganisms," Journal of Microbiological Methods, vol. 56, no. 3, pp. 339-347, 2004.

[19] L. Rodrigues, A. Moldes, J. Teixeira, and R. Oliveira, "Kinetic study of fermentative biosurfactant production by lactobacillus strains," Biochemical Engineering Journal, vol. 28, no. 2, pp. 109-116, 2006.

[20] C.-Y. Chen, S. C. Baker, and R. C. Darton, "The application of a high throughput analysis method for the screening of potential biosurfactants from natural sources," Journal of Microbiological Methods, vol. 70, no. 3, pp. 503-510, 2007.

[21] P. L. Du Noüy, "An interfacial tensiometer for universal use," The Journal of General Physiology, vol. 1, pp. 625-632, 1925.

[22] J. E. V. Ferreira, A. F. Figueiredo, J. P. Barbosa, and J. C. Pinheiro, "Chemometric study on molecules with anticancer properties," Chemometrics in Practical Applications, 2012.

[23] S. Altschul, T. L. Madden, A. A. Schäffer et al., "Gapped BLAST and PSI-BLAST: a new generation of protein database search programs," Nucleic Acids Research, vol. 25, no. 17, pp. 3389-3402, 1997.

[24] K. Tamura and M. Nei, "Estimation of the number of nucleotide substitutions in the control region of mitochondrial DNA in humans and Chimpanzees," Molecular Biology and Evolution, vol. 10, no. 3, pp. 512-526, 1993.

[25] R. Prasad, V. Kumar, M. Kumar, and S. Wang, "Fungal nanobionics: principles and applications," in Fungal Nanobionics: Principles and Applications, pp. 1-316, Springer Nature Singapore Private Ltd., Berlin, Germany, 2018.

[26] J. D. V. Fajardo, L. A. G. d. Souza, and S. S. Alfaia, "Características químicas de solos de várzeas sob diferentes sistemas de uso da terra, na calha dos rios baixo Solimões e médio Amazonas," Acta Amazonica, vol. 39, no. 4, pp. 731-740, 2009. 
[27] N. Fierer and R. B. Jackson, "The diversity and biogeography of soil bacterial communities," Proceedings of the National Academy of Sciences, vol. 103, no. 3, pp. 626-631, 2006.

[28] C. A. Hanson, J. A. Fuhrman, M. C. Horner-Devine, and J. B. H. Martiny, "Beyond biogeographic patterns: processes shaping the microbial landscape," Nature Reviews Microbiology, vol. 10, no. 7, pp. 497-506, 2012.

[29] S. D. Siciliano, A. S. Palmer, T. Winsley et al., "Soil fertility is associated with fungal and bacterial richness, whereas $\mathrm{PH}$ is associated with community composition in polar soil microbial communities," Soil Biology and Biochemistry, vol. 78, pp. 10-20, 2014.

[30] M. Delgado-Baquerizo, F. T. Maestre, P. B. Reich et al., "Carbon content and climate variability drive global soil bacterial diversity patterns," Ecological Monographs, vol. 86, no. 3, pp. 373-380, 2016.

[31] W. R. Wieder, J. Boehnert, and G. B. Bonan, "Evaluating soil biogeochemistry parameterizations in Earth system models with observations," Global Biogeochemical Cycles, vol. 28, no. 3, pp. 211-222, 2014.

[32] A. M. Eldin, Z. Kamel, and N. Hossam, "Isolation and genetic identification of yeast producing biosurfactants, evaluated by different screening methods," Microchemical Journal, vol. 146, pp. 309-314, 2018.

[33] S. Iqbal, Z. M. Khalid, and K. A. Malik, "Enhanced biodegradation and emulsification of crude oil and hyperproduction of biosurfactants by a gamma ray-induced mutant of Pseudomonas aeruginosa," Letters in Applied Microbiology, vol. 21, no. 3, pp. 176-179, 1995.

[34] A. A. Jimoh and J. Lin, "Biosurfactant: a new frontier for greener technology and environmental sustainability," Ecotoxicology and Environmental Safety, vol. 184, Article ID 109607, 2019.

[35] D. J. Brenner and J. J. Farmer, "Enterobacteriaceae. Bergey's manual of systematics of archaea and bacteria," in Bergey's Manual of Systematics of Archaea and Bacteria, pp. 1-24, Wiley, New York, NY, USA, 2015.

[36] A. Eddehech, Z. Zarai, F. Aloui et al., "Production, purification and biochemical characterization of a thermoactive, alkaline lipase from a newly isolated Serratia sp. W3 Tunisian strain," International Journal of Biological Macromolecules, vol. 123, pp. 792-800, 2019.

[37] C. Lin, X. Jia, Y. Fang et al., "Enhanced production of prodigiosin by Serratia marcescens FZSF02 in the form of pigment pellets," Electronic Journal of Biotechnology, vol. 40, pp. 58-64, 2019.

[38] S. Nalini and R. Parthasarathi, "Optimization of rhamnolipid biosurfactant production from Serratia rubidaea SNAU02 under solid-state fermentation and its biocontrol efficacy against Fusarium wilt of eggplant," Annals of Agrarian Science, vol. 16, no. 2, pp. 108-115, 2018.

[39] L. M. Ludueña, M. S. Anzuay, J. G. Angelini et al., "A fabra, and T taurian, "Strain Serratia sp. S119: a potential biofertilizer for peanut and maize and a model bacterium to study phosphate solubilization mechanisms," Applied Soil Ecology, vol. 126, pp. 107-112, 2018.

[40] W. Frederiksen, "Citrobacter," in Bergey's Manual of Systematics of Archaea and Bacteria, pp. 1-23, Wiley, New York, NY, USA, 2015.

[41] F. G. Priest and G. Fergus, "Paenibacillus," Bergey's Manual of Systematics of Archaea and Bacteria, pp. 1-40, 2015.

[42] A. R. Najafi, R. Roostaazad, M. Soleimani et al., "Comparison and modification of models in production of biosurfactant for Paenibacillus alvei and Bacillus mycoides and its effect on
MEOR efficiency," Journal of Petroleum Science and Engineering, vol. 128, pp. 177-183, 2015.

[43] F. Z. Mesbaiah, K. Eddouaouda, A. Badis et al., "Preliminary characterization of biosurfactant produced by a PAHdegrading Paenibacillus sp. under thermophilic conditions," Environmental Science and Pollution Research, vol. 23, no. 14, pp. 14221-14230, 2016.

[44] C. G. Anaukwu, C. C. Ezemba, V. N. Anakwenze et al., "Effect of biosurfactant produced by Citrobacter murliniae AF025369 and a synthetic surfactant on degradation of crude oil," Endorium, vol. 2, no. 1-6, 2016.

[45] E. Z. Gomaa and R. M. El-Meihy, "Bacterial biosurfactant from Citrobacter freundii MG812314.1 as a bioremoval tool of heavy metals from wastewater," Bulletin of the National Research Centre, vol. 43, no. 1, 2019.

[46] S. Dhail, "Isolation of potent biosurfactant producing bacteria from oil spilled marine water and marine sediments," African Journal of Biotechnology, vol. 11, no. 103, pp. 16751-16757, 2012.

[47] G. A. Płaza, M. Pacwa-Płociniczak, Z. Piotrowska-Seget, K. Jangid, and K. A. Wilk, "Agroindustrial wastes as unconventional substrates for growing of Bacillus strains and production of biosurfactant," Environment Protection Engineering, vol. 37, no. 3, pp. 63-71, 2011.

[48] P. A. Willumsen and U. Karlson, "Screening of bacteria, isolated from PAH-contaminated soils, for production of biosurfactants and bioemulsifiers," Biodegradation, vol. 7, no. 5, pp. 415-423, 1997. 